\title{
Flower density and winter damage of apricot and peach varieties
}

\author{
Szabó, Z. ${ }^{1}$, Veres, E. ${ }^{1}$, Soltész, M. ${ }^{2}$, Gregová, E. ${ }^{3}$, Benediková, D. ${ }^{3}$ \& Nyéki, J. ${ }^{1}$ \\ ${ }^{1}$ University Debrecen, Centre of Agricultural and Applited Economic Sciences, Debrecen \\ ${ }^{2}$ College of Kecskemét, Faculty of Horticulture, Kecskemét \\ ${ }^{3}$ Plant Production Research Centre, Slovak Republic, Piešt'any
}

\begin{abstract}
Summary: Hungary is located on the northern boundary of economical apricot and peach production. The present assortment of varieties and the actual, not adequately selected growing sites cause a permanent risk of winter and spring frosts in their cultivation. The field observations are performed at Debrecen, the Experiment Station Pallag, on 20 apricot and 21 peach varieties. The flower density among the varieties attained 3-4-fold differences. Three categories have been suggested for both species. The density was inferior in Hungary established varieties compared with the new varieties of foreign origin. The minimum temperatures of January 9,2009 was $-17,6{ }^{\circ} \mathrm{C}$, and of December 21,2009 also $-17,6{ }^{\circ} \mathrm{C}$. In some varieties the damage of buds attained $100 \%$. For estimating the yield security, we need to consider also the flower density and the frost damage together. For a mediocre yield, we need a flower density in both species of at least 0.2 living bud/cm. The results confirm the statement that in Hungary, the revision of growing sites is indispensable in order to develop a profitable and competitive apricot and peach growing industry.
\end{abstract}

Key words: apricot, peach, spring frost damage, flower bud density.

\section{Introduction}

As Hungary is on the northern border of the geographic area suitable for apricot and peach production, the growing site ought to be carefully selected from the point of view of security. Apricot and peach trees may suffer heavy frost damage in some years up to $100 \%$ (Szabó, 1997, Szabó \& Nyéki, 2004).

On the growing sites of the Great Plain yields are heavily affected in 2 or 4 years out of 10 years in general. At the same time, sweet and sour cherry as well as plum trees suffer damages 1-2 times in a 10 year long period if the site is threatened by frosts (Szabó, 1997).

In the recent years, the recognition of this risk resulted in a regular selection of growing sites as an important moment of development (e.g. apricot growing at Gönc).

The flower buds are developed during the former growing period and are subject to the influence of the load of fruits, the ratio between flower buds and vegetative buds and the development of fruiting structures. The information of flower bud density is a valid indicator of the potential of producing yields in the plantation. The pruning policies are adapted to contribute to the expected yields (Szabó, 2004). The number of flower buds per unit length of shoots is considered to be a standard date for predicting the future yield (Werner et al., 1988) and characterise the variety. The heaviest problem of production is due to the risk of frost damage during the winter and the late frosts of the spring. The resistance to winter frosts is relatively well developed especially in some fruit species (e.g. plum and apple), other species are rather susceptible (almond, peach, walnut). The low minimum temperatures and the duration of the cold $\left(-15^{\circ} \mathrm{C}\right)$ may damage almost all fruit species. If new varieties are tested, a quick orientation is obtained by artificial cooling in a refrigerator in order to determine the lethal temperature, $\mathrm{LT}_{50}$, as a decisive parameter. Conscientious with that date, the estimation of the expected damage and the profitability of a new variety is possible (Szalay, 2008).

\section{Materials and Methods}

The purpose of our observations is the rating of frost damages in varieties during the winter and spring of the critical year 2009-2010 at Debrecen Univerity, Regional Experimental Station, Pallag, where an assortment of fruit varieties offered an excellent opportunity for comparing the frost damage of the varieties. There, a series of 20 apricot and 21 peach varieties have been examined and evaluated regularly regarding frost damage suffered during the winter and early spring.

The ecological conditions of the site are coincident with the southern border of the Nyírség region, where the humus content of the soil was low $(0.8-1 \%)$, the heaviness according to the scale of Arany: 27-28, i.e. a sandy, slightly acid soil. The yearly precipitation is $530 \mathrm{~mm}$ as a mean, with $340 \mathrm{~mm}$ during the growing season with irregular distribution. The daily temperature minima in the critical period of the two years (2009-2010) are shown in Figure 1.

The first basic condition of a good yield is the number of flower buds (and their survival until the blooming). The 


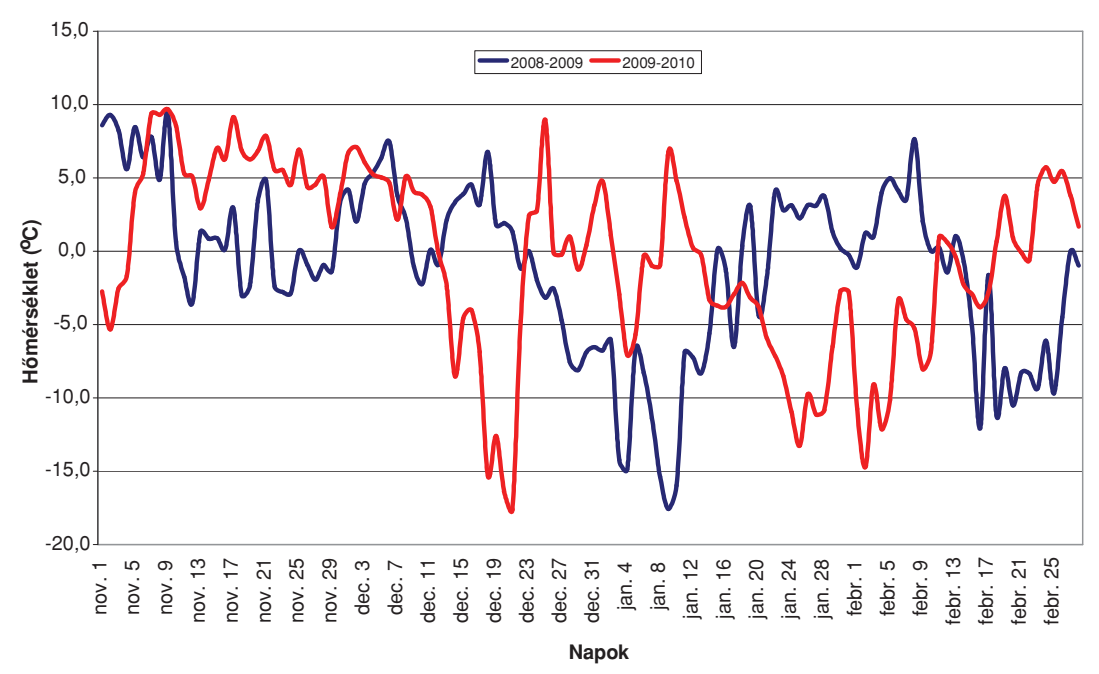

Figure 1. Daily minimum temperatures of the periods 2008 Nov. $1-2009$ Febr. 28 (blue) and 2009 Nov. 1 - 2010 Febr. 28 (red) (Debrecen-Pallag)

flower buds were counted on three trees per variety, on 10 shoots of each of them collected at $2 \mathrm{~m}$ height over the soil from the periphery of the tree crown. All buds of the sample shoots have been counted and examined.

The flower bud density is expressed by the number of buds per $\mathrm{cm}$ length of the shoot, i.e. buds/cm. In apricot, we could not find information, in the literature, related to flower bud densities of varieties. According the flower bud density, three categories of varieties have been distinguished: low $(<0.8 \mathrm{bud} / \mathrm{cm})$, mediocre $(0.8-1.3 \mathrm{bud} / \mathrm{cm})$ and high $(>1.2$ $\mathrm{bud} / \mathrm{cm})$.
The corresponding categories for peach varieties were: low $(<0.4 \mathrm{bud} / \mathrm{cm})$, mediocre $(0.41-0.6 \mathrm{bud} / \mathrm{cm})$ and high $(>0.6 \mathrm{bud} / \mathrm{cm})$ as described earlier (Szabó 2004).

\section{Results}

The winter temperature relations of the two years examined were rather variable, and suited for the study of frost damage in stone fruit species.

It was stated that the flower bud density of the apricot varieties established in Hungary was lower than that of the new varieties of foreign origin. It means that the majority of Hungarian varieties belong to the low bud density group, whereas the foreign varieties ranged from the mediocre to the high bud density group. The lowest bud-density was registered in 2009 between $0.58 \mathrm{bud} / \mathrm{cm}$ (Gönci magyar kajszi) and 1.77 $\mathrm{bud} / \mathrm{cm}$ (Ninfa). In 2010 the corresponding values were 0.52 $\mathrm{bud} / \mathrm{cm}$ (Ceglédi óriás) and $2.38 \mathrm{bud} / \mathrm{cm}$ (Alba). The frost damage of the flower buds was severe in both years, in some varieties attained $100 \%$ in $2 \mathrm{~m}$ height above ground. The less damage was found in 2009 at the variety Ivano Liverani (72.6\%) and in 2010 at Antonio Errani (17.9\%) (Table 1). In 2010, we could state that the Hungarian varieties tolerated better the low temperature. For the grower, the two properties examined (bud density and frost tolerance) together decide

Table 1. Flower bud density and frost damage of apricot varieties

\begin{tabular}{|c|c|c|c|c|c|c|c|c|c|}
\hline \multicolumn{5}{|c|}{2009} & \multicolumn{5}{|c|}{2010} \\
\hline Variety & $\begin{array}{r}\text { Den } \\
\text { flow } \\
\text { (bu }\end{array}$ & $\begin{array}{l}\text { of } \\
\text { mods } \\
\text { m) }\end{array}$ & $\begin{array}{c}\text { Frost } \\
\text { damage of } \\
\text { flower buds } \\
(\%)\end{array}$ & $\begin{array}{c}\text { Living } \\
\text { flower } \\
\text { buds } \\
\text { (bud/cm) }\end{array}$ & Variety & $\begin{array}{r}\text { Den } \\
\text { flowe } \\
\text { (bu }\end{array}$ & $\begin{array}{l}\text { ity of } \\
\text { buds } \\
\text { /cm) }\end{array}$ & $\begin{array}{c}\text { Frost } \\
\text { damage of } \\
\text { flower buds } \\
(\%)\end{array}$ & $\begin{array}{l}\text { Living } \\
\text { flower } \\
\text { buds } \\
\text { (bud/cm) }\end{array}$ \\
\hline Gönci magyar kajszi & 0.58 & \multirow{5}{*}{$\underline{z}$} & \begin{tabular}{|l|}
99.5 \\
\end{tabular} & 0.00 & Ceglédi óriás & 0.52 & \multirow{10}{*}{$\stackrel{3}{0}$} & 27.1 & 0.38 \\
\hline Mandulakajszi & 0.69 & & 94.0 & 0.04 & Gönci magyar kajszi & 0.57 & & 54.6 & 0.26 \\
\hline Tardicot & 0.75 & & 98.1 & 0.01 & Bella 'd Imola & 0.60 & & 66.4 & 0.20 \\
\hline Palumella & 0.80 & & 97.0 & 0.02 & Palumella & 0.67 & & 61.8 & 0.25 \\
\hline Pisana & 0.80 & & 96.2 & 0.03 & Mandulakajszi & 0.67 & & 54.3 & 0.31 \\
\hline Bergeron & 0.87 & \multirow{11}{*}{ 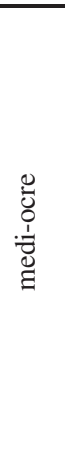 } & 91.6 & 0.07 & Bergeron & 0.69 & & 63.0 & 0.26 \\
\hline Bella d' Imola & 0.89 & & 89.9 & 0.09 & Ceglédi Piroska & 0.71 & & 42.8 & 0.41 \\
\hline Ceglédi Piroska & 0.90 & & 96.0 & 0.04 & \begin{tabular}{|l|} 
Vitillo \\
\end{tabular} & 0.76 & & 100.0 & 0.00 \\
\hline Antonio Errani & 0.94 & & 93.4 & 0.06 & Latter Sabattini & 0.77 & & 79.4 & 0.16 \\
\hline Ivano Liverani & 0.97 & & 72.5 & 0.27 & Ninfa & 0.78 & & 100.0 & 0.00 \\
\hline Latter Sabattini & 0.98 & & 95.7 & 0.04 & Tardicot & 1.09 & \multirow{3}{*}{ 它 。 } & 57.1 & 0.47 \\
\hline Ceglédi óriás & 1.00 & & 96.8 & 0.03 & Sylred & 1.19 & & 83.7 & 0.19 \\
\hline Marietta & 1.00 & & 98.8 & 0.01 & Ivano Liverani & 1.20 & & 59.6 & 0.49 \\
\hline Alba & 1.00 & & 95.1 & 0.05 & Antonio Errani & 1.47 & \multirow{3}{*}{..ㅁำ } & 17.9 & 1.21 \\
\hline Goldrich & 1.00 & & 89.9 & 0.10 & Goldrich & 1.48 & & 83.5 & 0.24 \\
\hline Vitillo & 1.01 & & 92.1 & 0.08 & Silver Cot & 1.54 & & 99.5 & 0.01 \\
\hline Silver Cot & 1.10 & & 99.4 & 0.01 & Pisana & 1.58 & & 55.1 & 0.71 \\
\hline Robada & 1.14 & & 92.3 & 0.09 & Robada & 1.85 & & 85.8 & 0.26 \\
\hline Sylred & 1.62 & \multirow{2}{*}{$\frac{.}{.000}$} & 98.4 & 0.03 & Marietta & 2.18 & & 85.8 & 0.31 \\
\hline Ninfa & 1.77 & & 100.0 & 0.00 & Alba & 2.38 & & 78.3 & 0.52 \\
\hline
\end{tabular}


Table 2. Flower bud density and frost damage in buds of peach

\begin{tabular}{|c|c|c|c|c|c|c|c|c|c|}
\hline \multicolumn{5}{|c|}{2009} & \multicolumn{5}{|c|}{2010} \\
\hline \multirow{2}{*}{\begin{tabular}{|l} 
Variety \\
Michellini
\end{tabular}} & \multicolumn{2}{|c|}{$\begin{array}{l}\text { Density of } \\
\text { flower buds } \\
\text { (bud/cm) }\end{array}$} & \multirow{2}{*}{\begin{tabular}{|c|c}
$\begin{array}{c}\text { Frost damage } \\
\text { of flower buds } \\
(\%)\end{array}$ \\
71.7 \\
\end{tabular}} & \multirow{2}{*}{\begin{tabular}{|c}
$\begin{array}{c}\text { Living } \\
\text { flower buds } \\
\text { (bud/cm) }\end{array}$ \\
0.10
\end{tabular}} & \multirow{2}{*}{\begin{tabular}{|r|} 
Variety \\
Silver Giant \\
\end{tabular}} & \multicolumn{2}{|c|}{$\begin{array}{c}\text { Density of } \\
\text { flower buds } \\
\text { (bud/cm) }\end{array}$} & \multirow{2}{*}{\begin{tabular}{|c}
$\begin{array}{c}\text { Frost damage } \\
\text { of flower } \\
\text { buds }(\boldsymbol{\%})\end{array}$ \\
97.9 \\
\end{tabular}} & \multirow{2}{*}{$\begin{array}{c}\begin{array}{c}\text { Living } \\
\text { flower } \\
\text { buds } \\
\text { (bud/cm) }\end{array} \\
0.01\end{array}$} \\
\hline & 0.36 & 3 & & & & 0.25 & \multirow{10}{*}{$\underline{z}$} & & \\
\hline Silver Giant & 0.4 & 으 & 100.0 & 0.00 & Red Moon & 0.26 & & 63.8 & 0.10 \\
\hline Max 7 & 0.51 & \multirow{5}{*}{ 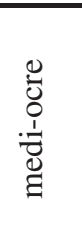 } & 75.5 & 0.13 & Max 7 & 0.30 & & 86.9 & 0.04 \\
\hline Redhaven & 0.53 & & 71.6 & 0.15 & Redhaven & 0.31 & & 56.2 & 0.14 \\
\hline California & 0.57 & & 71.9 & 0.16 & Sweet Red & 0.32 & & 100.0 & 0.00 \\
\hline Mariska & 0.58 & & 63.6 & 0.21 & Champion & 0.35 & & 33.4 & 0.24 \\
\hline Early Redhaven & 0.59 & & 70.3 & 0.18 & Fairlane & 0.38 & & 68.5 & 0.12 \\
\hline Big Top & 0.62 & \multirow{13}{*}{. } & 90.5 & 0.06 & Alice & 0.38 & & 96.4 & 0.01 \\
\hline Fairlane & 0.62 & & 72.3 & 0.17 & Early Redhaven & 0.38 & & 86.0 & 0.05 \\
\hline Red Moon & 0.64 & & 82.8 & 0.11 & Big Top & 0.39 & & 100.0 & 0.00 \\
\hline Rich Lady & 0.66 & & 85.3 & 0.10 & Michellini & 0.41 & \multirow{7}{*}{ 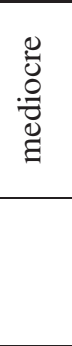 } & 55.8 & 0.18 \\
\hline Sweet Red & 0.66 & & 75.5 & 0.16 & Maria Aurélia & 0.41 & & 55.8 & 0.18 \\
\hline Vista Rich & 0.66 & & 90.8 & 0.06 & Rich Lady & 0.44 & & 99.3 & 0.00 \\
\hline Maria Aurélia & 0.67 & & 75.9 & 0.16 & Fantasia & 0.44 & & 77.3 & 0.10 \\
\hline Champion & 0.72 & & 83.5 & 0.12 & Mariska & 0.48 & & 75.4 & 0.12 \\
\hline Silver King & 0.75 & & 61.8 & 0.29 & Silver King & 0.49 & & 91.8 & 0.04 \\
\hline Ambra & 0.78 & & 81.8 & 0.14 & Vista Rich & 0.54 & & 48.3 & 0.28 \\
\hline Guerriera & 0.81 & & 70.7 & 0.24 & Ambra & 0.60 & \multirow{3}{*}{ 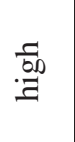 } & 91.8 & 0.05 \\
\hline Alice & 0.86 & & 71.7 & 0.24 & California & 0.79 & & 11.6 & 0.70 \\
\hline Fantasia & 0.95 & & 75.2 & 0.24 & Guerriera & 0.93 & & 100.0 & 0.00 \\
\hline
\end{tabular}

the number of living flower buds in the spring. According to our experiences the critical minimum of bud density promising a weak-mediocre yield need a bud density more than $0.1 \mathrm{bud} / \mathrm{cm}$. In 2009, only one single variety occurred: Ivano Liverani. Almost similar values are found in Bella d' Imola, Goldrich, Vitillo and Robada varieties. In 2010, much larger differences appeared in both bud density and frost damage. There were several varieties with surviving flower buds, and one of them was really outstanding: Antonio Errani $(1.21 \mathrm{bud} / \mathrm{cm})$.

In peach, also large differences showed up between the two years in bud density, but the values were in 2009 higher than in 2010. The bud densities varied in 2009 between 0.36 bud $/ \mathrm{cm}$ (Michellini) and $0.95 \mathrm{bud} / \mathrm{cm}$ (Fantasia). In 2010, the values were $0.25 \mathrm{bud} / \mathrm{cm}$ (Silver Giant) and $0.93 \mathrm{bud} / \mathrm{cm}$ (Guerriera). In peach also occurred $100 \%$ frost damage, but all of them were nectarines (Silver Giant, Sweet red, Big Top, Guerriera). Those data indicate the higher frostsusceptibility of nectarines. The less damage was registered in 2009 at the variety Silver King (61.8\%), in 2010 at Champion (33.4\%) as shown in Table 2).

A high flower density is also a means to moderate the damage caused by frost. In a variety with high flower density, still a mediocre yield could be achieved by thoughtful pruning. In flower bud densities (bud/cm) large differences substantial differences showed up. The majority of peach varieties displayed a high rate of fertilisation ( $>40 \%)$, therefore a bud density of $>2.2 \mathrm{bud} / \mathrm{cm}$ may produce higher than mediocre yield. The frost damage is, however, unevenly distributed in the crown, therefore it is recommended that pruning should be postponed until bloom. The less hurt parts should be maintained on the tree, which are recognised at bloom. In 2009, five varieties, whereas in 2010, thee varieties proved to have enough flowers to produce acceptable yields.

\section{Conclusions}

At growing sites, where winter- and spring frosts are threatening the yields, the importance to choose right varieties as well as to apply technological elements and measures of moderating frost damage are especially outstanding. Varieties of high susceptibility are not recommended for those growing sites because the high frequency of damages may jeopardise the economy of production.

The adaptation of new varieties in Hungary requires a thorough scrutiny of the security of yields. The key character is the frost tolerance of the variety, moreover, the flower bud density and its fertility relations. For the security in fruit 
growing, the varieties recommended ought to be determined in all growing regions separately. The flower density and the location of buds are variety characters, and should be included into the description of the variety. Flower density is an important component of fertility especially under critical conditions. Thus the danger of frost is mitigated by high flower density, whereas low flower density requires higher security of productions, or in other word, susceptible varieties should grown where the frost damage is less frequent.

\section{Acknowledgements}

The research was supported by the projects OM00042/2008, OM-00270/2008, OM-00265/2008.

\section{Reference}

Szabó, Z. (1997): A kedvezőtlen meteorológiai hatások mérséklése. 353-359. (In: Soltész, M. (edit.): Integrált gyümölcstermesztés.) Mezőgazda Kiadó, Budapest, 843 p.

Szabó, Z. (2004): Csonthéjasok termésbiztonságának egyes tényezője. MTA doktori értekezés, Budapest.

Szabó, Z. \& Nyéki J. (2004): Az őszibaracktermelés kritikus pontjai. ,Agro-21” Füzetek, 34: 46-60.

Szalai, I. (1994): A növények élete I-II. JATE Press. Szeged.

Szalay, L. (2008): Development and cold hordiness of flower buds of stone fruits. (In Nyéki, J., Soltész, M., Szabó, Z., (edit.): Morphology, biology and fertility of flowers in temperate zone fruits.) Akadémiai Kiadó, Budapest 63-82.

Werner, D. J., Mowrey, B. D. \& Chaparro, J. X. (1988): Variability in flower bud number among peach cultivars. HortScience, 23 (3): 578-580. 